\title{
COMPARATIVE ANALYSIS OF DIFFERENT METHODS FOR BODY FAT ASSESSMENT IN ADOLESCENTS
}

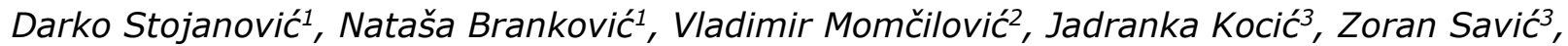 \\ Zoran Momčilović2, Vesko Milenković3
}

\begin{abstract}
In order to determine the differences between results obtained by using two different methods for estimating the body fat percentage in adolescents, a comparative analysis was performed with bioelectrical impedance method and a traditional method for assessing body composition by skinfold measurement. The sample of this study consisted of 86 seventh grade students of elementary school (42 girls and 44 boys). Body fat percentage was estimated using electronic scale through bioelectrical impedance for assessing the body composition "OMRON BF-511, Japan" and traditionally by measuring skinfolds with caliper and further calculations using equations according to Slaughter (1988). After analyzing the obtained results, it was found that no statistically significant differences were present between body fat percentage obtained by the method of bioelectrical impedance and the method of skinfold measurement of triceps and subscapular $(p=0.711)$ and triceps and calf $(p=0.850)$ in girls, while statistically significant differences were found between the results of these two methods $(p=0.001 ; p=$ 0.009 ) in boys. Comparison of two most commonly used methods for assessing body fat percentage shown similar results in girls, while in boys, significant differences were present between measurements of these two methods.
\end{abstract}

Acta Medica Medianae 2019;58(3):153-158.

Key words: body fat, BIA, skinfolds, comparison, adolescents

\footnotetext{
${ }^{1}$ University of Niš, Faculty of Sport and Physical Education, Niš, Serbia

2University of Niš, Pedagogical Faculty in Vranje, Vranje, Serbia ${ }^{3}$ University of Priština - Kosovska Mitrovica, Faculty of Sport and Physical Education, Leposavić, Serbia
}

Contact: Darko Stojanović

Blvd Nemanjića 66a/3, 18000 Niš, Serbia

E-mail: darko89_nish@hotmail.com

\section{Introduction}

There is an increasing demand for body composition analysis in personal use or homecare to monitor weight status, weight loss therapy, or outcome of strength or endurance exercise (1) and the most important fact to monitor general health status of children and adolescents because of presence of obesity prevalence among them.

The body composition represents different tissues within human body, as well as their mutual relationship. According to the American Association for Health, Physical Education, Recreation and Dance
(2), the body composition represents the ratio of fat, muscle and bone tissue in the overall body mass. Body composition is defined as a fitness component that is closely related to the relative values of muscle, fat, water, bones, and other vital parts of the human body $(3,4)$. In practice, the most commonly used methods for determining the composition of the body are based on a two-compartment model where total body mass consists of two parts: fat and fat free mass (5). Currently, there is a range of methods for measuring body composition. They vary depending on instrumental or personal needs, as well as in how accurately the observed values are determined (6).

For the evaluation of fat tissue, direct and indirect methods are used. In practice, methods that have been shown to be much more accurate and valid are direct methods such as dual-energy X-ray absorptiometry (DEXA), hydrodensitometry, plethysmography (BOD POD), ultrasonic method, magnetic resonance and the most accessible, but not as accurate as previously mentioned, method of bioelectrical impedance (BIA). Less accurate are indirect methods where results are obtained by measuring a number of anthropometric characteristics to determine the body fat percentage. The anthropometric method involves measuring body weight, body height, body circumference, skinfolds and diameters at reference points from which individual parts of the 
body composition can be calculated by using equations (7). The most famous and most commonly used traditional method which is based on a twocomponent model of body composition is skinfold thickness measurement. Such methods require trained gauges and knowledge of anatomy of the body. According to the measurement protocol, measurements are taken at least twice, so that the final results can be traced, as opposed to the modern method for assessing the body composition by bioelectrical impedance where the procedure is fairly simple, fast and allows almost instantaneous results (8, 9).

The bioelectrical impedance method (BIA) is a non-invasive, fast, simple and reliable method which evaluates body composition by emission of a safe low-frequency current through the body structure and measures the impedance (resistance) of various tissues. The current flows through the body fluid that contains electrolytes without excessive resistance. In addition, the fat tissue contains only small amounts of water, so current will not easily pass through fat tissue. Unlike body fat component, a fat free component, which contains large amounts of body fluid and, therefore, electrolytes, is a better conductor of the current. The latest generations of BIA devices allow precise calculations of body fat, body cell mass, extracellular mass, intracellular water and extracellular water as well as several other derivatives (10).

\section{The aim}

The aim of this study was to determine body fat percent of elementary school students using indirect (two equations for skinfold thickness measurement) and direct (BIA) field methods for assessing body fat percentage and to find out the differences among these methods.

\section{Material and methods}

The sample of this study consisted of $86-7$ th grade elementary school students, age 13 years \pm 6 months. The sample was divided into two subsamples: girls $(n=42$; BMI $=19.97)$ and boys $(n=44$; BMI $=20.59$ ). The sample includes every student who volunteered to participate in the research with the consent of their parents. An additional requirement was that students during the testing were clinically healthy. Subjects were familiar with basic methods, procedures and research objectives.

For assessment of body fat percent by indirect method, anthropometric measurements of three skinfolds were performed: triceps (TRI), subscapular (SUB) and calf (CA). Measurement of skinfold thickness was carried out according to the methodology recommended by the International Biological Program (11) using the GPM GmbH GPM (GPM GmbH Switzerland) with a measurement accuracy of 0.2 $\mathrm{mm}$. The pressure of the instrument clamps on the skin and subcutaneous tissue was standard (10gr/ $\mathrm{mm}^{2}$ ). The measurement result was read 2 seconds after the grip had been caught on the skinfold. The results of the fat tissue from indirect method were calculated using the following equations according to Slaughter (12):

For girls:

1.) BF\% $\%_{\text {TRI }}+\mathrm{CA}=.610(\mathrm{TRI}+\mathrm{CA})+5.1$

2.) $\mathrm{BF}_{\mathrm{TRI}}+\mathrm{SUB}=1.33(\mathrm{TRI}+\mathrm{SUB})-.013$

(TRI+SUB)2 - 2 For boys:

1.) BF\% ${ }_{\text {TRI }+C A}=.735($ TRI+CA $)+1.0$

2.) $B F \%$ TRI+SUB $=1.21$ (TRI+SUB) - .008

(TRI+ SUB) 2 - 3.4

For assessment of body fat percent by direct method, bioelectrical impedance analysis (BIA) method was used with single frequency tetrapolar hand-to-foot electronic scale OMRON-BF511 (Omron, Japan), which, according to the technical specifications of the device, gives results with a precision of $0.1 \%$. Before measurements, the previously obtained body height data (anthropometer by Martin), age and sex of the subjects were entered using the device key. Subjects were measured barefoot in light underwear following manufacturer's instructions. The single frequency hand-to-foot BIA devices provides estimated values for $\mathrm{BF} \%$ by passing an low frequency (50hz) alternating current through the subject than calculate impedance (ohms) of different body tissues.

\section{Statistical analysis}

In order to determine the differences in results between the indirect and the direct method for estimating body fat percent, a t-test for dependent samples (paired t-test) was applied at the level of statistical significance $p<0.05$.

For raw data processing and statistical analysis, statistical software - STATISTICA 8.0 for Windows (StatSoft, Inc., Tulsa, OK), was used.

\section{Results}

The results of t-test paired samples analyses of repeated measurements and comparison of two methods for estimating body fat percentage for girls were showed in tables 1-2. T-test analysis (Table 1.) showed no significant differences between body fat percentage measured from triceps and calf skinfolds equation $(\mathrm{BF} \%=22.66)$ and body fat percentage measured from Omron BF-511 bioelectrical impedance scale $(B F \%=22.80)$. Also, $t$-test analysis (Table 2.) showed no significant differences between body fat percentage measured from triceps and subscapular skinfolds equation $(\mathrm{BF} \%=22.59)$ and body fat percentage measured from Omron BF-511 bioelectrical impedance scale $(\mathrm{BF} \%=22.80)$.

The results of $\mathrm{t}$-test paired samples analyses of repeated measurements and comparison of two methods for estimating body fat percentage for boys were showed in tables 3-4. T-test analysis showed significant differences $(p=0.009)$ between body fat percentage measured with triceps and calf skinfolds equation $(\mathrm{BF} \%=19.56)$ and body fat percentage measured from Omron BF-511 bioelectrical impedance scale $(\mathrm{BF} \%=17.65)$. 
Table 1. T-test results of body fat percentage measured by triceps and calf skinfolds equation and bioelectrical impedance analysis for girls

\begin{tabular}{|llcccc||}
\hline Variable & N & Mean & Std. Dev. & t & p \\
\hline \hline BF\%tRI+CA & 42 & 22.66 & 5.681 & -0.191 & 0.850 \\
BF\%ora & 42 & 22.80 & 7.556 & & \\
\hline
\end{tabular}

TRI+CA - body fat percent from triceps and calf skinfold equation; BIA - body fat percent from bioelectrical impedance analyzer Omron BF-511

Table 2. T-test results of body fat percentage measured by triceps and subscapular skinfolds equation and bioelectrical impedance analysis for girls

\begin{tabular}{|llcccc||}
\hline Variable & N & Mean & Std. Dev. & t & p \\
\hline \hline BF\%тrI+SUB & 42 & 22.59 & 5.145 & & \\
BF\% & 42 & 22.80 & 7.556 & -0.374 & 0.711 \\
\hline
\end{tabular}

TRI+SUB - body fat percent from triceps and subscapular skinfold equation; BIA - body fat percent from bioelectrical impedance analyzer Omron BF-511

T-test analysis showed significant differences $(p=0.001)$ between body fat percentage measured with triceps and subscapular skinfolds equation
$(\mathrm{BF} \%=19.88)$ and body fat percentage measured from Omron BF-511 bioelectrical impedance scale $(\mathrm{BF} \%=17.65)$.

Table 3. T-test results of body fat percentage measured by triceps and calf skinfolds equation and bioelectrical impedance analysis for boys

\begin{tabular}{|llcccc|}
\hline Variable & N & Mean & Std. Dev. & t & p \\
\hline \hline BF\%trI+CA & 44 & 19.56 & 6.662 & 2.739 & $0.009 *$ \\
BF\% & 44 & 17.65 & 7.357 & & \\
\hline
\end{tabular}

TRI+CA - body fat percent from triceps and calf skinfold equation; BIA - body fat percent from bioelectrical impedance analyzer Omron BF-511;* - significant at $\mathrm{p}<0.01$

Table 4. T-test results of body fat percentage measured by triceps and subscapular skinfolds equation and bioelectrical impedance analysis for boys

\begin{tabular}{|lllcll||}
\hline Variable & N & Mean & Std. Dev. & t & p \\
\hline \hline BF\%tRI+sUB & 44 & 19.88 & 6.289 & 3.645 & $0.001^{*}$ \\
BF\%oвIA & 44 & 17.65 & 7.357 & & \\
\hline
\end{tabular}

TRI+SUB - body fat percent from triceps and subscapular skinfold equation; BIA - body fat percent from bioelectrical impedance analyzer Omron BF-511; * - significant at $\mathrm{p}<0.01$

\section{Discussion}

The purpose of this study was to determine body fat percent of elementary school students using two field methods for assessing body fat percentage and to find out the differences among these methods. Skinfold measurements and bioelectrical impedance analysis (BIA) are popular and most commonly used methods for assessing body composition in children and adolescents due to their cost efficiency and ease of use.

Measurement of some skinfolds requires the 
removal of clothing, which can be awkward in some testing situations (13). Compared to other choices of skinfold sites, measuring the calf and triceps skinfolds and the subsequent prediction of percent body fat (\% BF) (12) can be used to assess body composition of children in public settings while remaining sensitive to issues of privacy that have become increasingly prevalent (14). Another good thing from practical point of view is measurement speed when using only two skinfold measurement, it is as fast as measuring with BIA.

Bioelectrical impedance analysis (BIA) also represents a simple, inexpensive and noninvasive method for assessing body composition that has broad application in research laboratories, hospitals, private clinics, health centers and schools (15). The human factor plays an important part when measurements are carried out using calipers. It is important for the person conducting the measurements to be sufficiently experienced. Measurements based on BIA methods bring some other factors that significantly influence accuracy of these measurements, such as body hydration, abnormalities in body composition, underweight or overweight. Therefore, when using BIA methods, the only results considered valid are those of individuals with BMI ranging between 18.5 and $34 \mathrm{~kg} / \mathrm{m}^{2}(6,16-19)$ which is in accordance with BMI values from population in this study (BMI=19.97 for girls and $B M I=20.59$ for boys).

The results from this study showed no significant differences between skinfold and BIA methods in girls. Triceps and calf skinfold equation $(\mathrm{BF} \%=$ 22.66) gave closer values to BIA (BF\%bia= 22.80$)$, than triceps and subscapular skinfold equation (BF\% $=22.59$ ) in girls. The results in boys showed that body fat percent from both skinfold equations statistically differ from BIA values. Triceps and calf skinfold equation $(B F \%=19.56)$ and triceps and subscapular skinfold equation $(B F \%=19.88)$, gave higher values than BIA $(B F \%=17.56)$. In accordance with these results, some studies reported that the triceps and calf skinfold equation overestimated BF\% in boys (14), as well as triceps and subscapular skinfold equation (20). In their study, Čokorilo et al. reported no significant differences between skinfold method and BIA method results in adult females (8). Some researchers reported opposite results, that four different skinfold prediction equations underestimated BF\% 8 to 12 year old boys and girls (21).
Also, Parker et al., reported that the sum of the triceps and subscapular skinfolds underestimated of $\mathrm{BF} \%$ in 10 to 14 year old boys (22). Janz et al., reported that the triceps and calf skinfolds equation delivered by Slaughter (12), overestimated of BF\% in girls, and the total error increased in males with higher levels of maturation (23). On another side, the investigation of the accuracy of single-frequency BIA provided inconsistent results, with some studies showing a good accuracy $(1,24)$ and others reporting only a poor agreement between BIA and reference methods (25).

The majority of mentioned authors have reference method like DEXA for comparison of agreement between methods, so it is very difficult to claim from results of this study which method is more accurate. In the absence of reference method as a gold standard, it is impossible to know whether any of the methods investigated here is providing a "true" measure of body fat percentage (26). Also, we must consider that equations derived more than 30 years ago (12), possibly no longer represent the body fat characteristics of children today because of increasing prevalence of overweight and obesity in adolescents (14).

\section{Conclusion}

In summary, the present study results showed that two methods are interchangeable only for girls, while for boys there are significant differences between methods. From practical point of view, most suitable method for body fat assessment for girls is triceps and calf skinfold equation, it is fast and good for public use because do not require the removal of clothing. Based on the results of this study it is impossible to suggest which method is more accurate for body fat assessment in girls or boys because of the absence of reference method for comparison. It can be concluded that these methods are more appropriate for assessing body fat of large population rather than an accurate measurement of individuals. According to many studies these methods are population sensitive, so we must imply that obtained results refers only to population from this study. Furthermore, future studies should aim to replicate results on different population with the reference method, also to aim at the development and validity of new equations for adolescents. 


\section{References}

1. Bosy-Westphal A, Later W, Hitze B, Sato T, Kossel E, Glüer C-C, et al. Accuracy of Bioelectrical Impedance Consumer Devices for Measurement of Body Composition in Comparison to Whole Body Magnetic Resonance Imaging and Dual X-Ray Absorptiometry. Obesity Facts 2008;1(6):319-24. [CrossRef] [PubMed]

2. Macswegin P. Physical best: The AAHPERD guide to physical fitness education and assessment. AAHPERD 1989.

3. Corbin $C B$, Lindsey R. Concepts of fitness and wellness, with laboratories: Custom publication for Vanier College. Chicago, IL: McGraw-Hill; 1997.

4. Solway A. Exercise - from birth to old age. Capstone Global Library Ltd; 2014.

5. Ellis KJ. Selected Body Composition Methods Can Be Used in Field Studies. The Journal of Nutrition 2001; 131(5):1589S-95S. [CrossRef] [PubMed]

6. Brtková, Mirianna, et al. Body composition of undergraduates-comparison of four different measurement methods. Physical Activity Review 2014; 2:38-44.

7. Siri, WE. Body composition from fluid spaces and density: analysis of methods. 1961. Nutrition 1993; 9(5): 480-91. [CrossRef] [PubMed]

8. Čokorilo N, Mikalački M, Korovljev D. Merenje procenta masnog tkiva modifikovanom metodom po $\mathrm{Ma}$ teigka i BIA metodom. Glasnik Antropološkog društva Srbije 2010; 45:411-418.

9. Stojanović $T$, Bešić $Đ$, Stojanović $D$, Lilić $L j$, Zadražnik $M$. The effects of short-term preseason combined training on body composition in elite female volleyball players. Anthropological Notebooks 2018; 24(1):8595. [CrossRef]

10. Stojiljković S, Juhas I, Mazić S, Nešić D. Efekti programa aerobnog trčanja na telesni sastav. U S. Stojiljković (Ur.) Međunarodna naučna konferencija „Fizička aktivnost i zdravlje", Zbornik radova (str. 39-44). Beograd: Fakultet sporta i fizičkog vaspitanja 2007.

11. Weiner JS, Lourie JA. A Guide to Field Methods. Human Biology1969.

12. Slaughter MH, Lohman TG, Boileau R, Horswill CA, Stillman RJ, Van Loan MD, et al. Skinfold equations for estimation of body fatness in children and youth. Human biology 1988; 60:709-23. [CrossRef] [PubMed]

13. Jackson AS, Pollock ML. Practical Assessment of Body Composition. The Physician and Sportsmedicine 1985; 13(5):76-90. [CrossRef] [PubMed]

14. Mooney A, Kelsey L, Fellingham GW, George JD, Hager RL, Myrer JW, et al. Assessing Body Composition of Children and Adolescents Using Dual-Energy X-Ray Absorptiometry, Skinfolds, and Electrical Impedance. Measurement in Physical Education and Exercise Science 2011;15(1):2-17. [CrossRef]

15. Pateyjohns IR, Brinkworth GD, Buckley JD, Noakes M, Clifton PM. Comparison of Three Bioelectrical Imped- ance Methods with DXA in Overweight and Obese Men. Obesity 2006;14(11):2064-70.

[CrossRef] [PubMed]

16. McRae MP. Male and female differences in variability with estimating body fat composition using skinfold calipers. Journal of Chiropractic Medicine 2010; 9(4): 157-61. [CrossRef] [PubMed]

17. Kyle UG, Bosaeus I, De Lorenzo AD, Deurenberg $P$, Elia M, Gomez JM, et al. Composition of the ESPEN Working Group: Bioelectrical impedance analysis-part I: review of principles and methods. Clinical Nutrition 2004; 23(5): 1226-43. [CrossRef] [PubMed]

18. Kyle UG, Bosaeus I, De Lorenzo AD, Deurenberg $P$, Elia M, Gomez JM, et al. Bioelectrical impedance analysis-part II: utilization in clinical practice. Clinical Nutrition 2004; 23(6): 1430-53. [CrossRef] [PubMed]

19. Shafer KJ, Siders WA, Johnson LK, Lukaski HC. Validity of segmental multiple-frequency bioelectrical impedance analysis to estimate body composition of adults across a range of body mass indexes. Nutrition 2009; 25(1): 25-32. [CrossRef] [PubMed]

20. Reilly JJ, Wilson J, Durnin JV. Determination of body composition from skinfold thickness: a validation study. Archives of Disease in Childhood 1995; 73(4):305-10. [CrossRef] [PubMed]

21. Wells JC, Fuller NJ, Dewit O, Fewtrell MS, Elia M, Cole TJ. Four-component model of body composition in children: density and hydration of fat-free mass and comparison with simpler models. The American Journal of Clinical Nutrition 1999; 69(5):904-12. [CrossRef] [PubMed]

22. Parker L, Reilly JJ, Slater C, Wells JC, Pitsiladis Y. Validity of Six Field and Laboratory Methods for Measurement of Body Composition in Boys. Obesity Research 2003;11(7):852-8. [CrossRef] [PubMed]

23. Janz KF, Nielsen DH, Cassady SL, Cook JS, Wu Y-T, Hansen JR. Cross-validation of the Slaughter skinfold equations for children and adolescents. Medicine \& Science in Sports \& Exercise 1993;25(9): 1070-6. [CrossRef] [PubMed]

24. Thompson R, Brinkworth GD, Buckley JD, Noakes M, Clifton PM. Good agreement between bioelectrical impedance and dual-energy X-ray absorptiometry for estimating changes in body composition during weight loss in overweight young women. Clin Nutr 2007;26 (6): 771-7. [CrossRef] [PubMed]

25. Frisard MI, Greenway FL, Delany JP. Comparison of methods to assess body composition changes during a period of weight loss. Obes Res 2005; 13(5): 845-54. [CrossRef] [PubMed]

26. Gutin B, Litaker M, Islam S, Manos T, Smith C, Treiber F. Body-composition measurement in 9-11-y-old children by dual-energy X-ray absorptiometry, skinfold-thickness measurements, and bioimpedance analysis. The American Journal of Clinical Nutrition 1996; 63(3):287-92. [CrossRef] [PubMed] 


\title{
KOMPARATIVNA ANALIZA RAZLIČITIH METODA ZA PROCENU MASNOG TKIVA KOD ADOLESCENATA
}

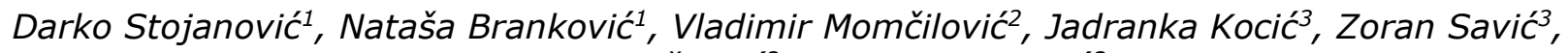 \\ Zoran Momčilović2, Vesko Milenković3
}

${ }^{1}$ Univerzitet u Nišu, Fakultet sporta i fizičkog vaspitanja, Niš, Srbija
${ }^{2}$ Univerzitet u Nišu, Pedagoški fakultet u Vranju, Vranje, Srbija
${ }^{3}$ Univerzitet u Prištini sa sedištem u Kosovskoj Mitrovici, Fakultet za sport i fizičko vaspitanje, Leposavić, Srbija

Kontakt: Darko Stojanović

Bulevar Nemanjića 66a/3, 18000 Niš, Srbija

E-mail: darko89_nish@hotmail.com

Sa ciljem da se utvrde razlike između rezultata dobijenih primenom različitih metoda za procenu količine masnog tkiva u organizmu kod adolescenata, izvršena je komparativna analiza metode bioelektrične impedanse i tradicionalne metode za procenu telesne kompozicije merenjem kožnih nabora. Uzorak ispitanika činilo je 86 učenika sedmog razreda osnovne škole (42 devojčice i 44 dečaka). Količina masnog tkiva procenjivana je pomoću vage, koja koristi bioelektričnu impedansu za procenu telesne kompozicije, "OMRON BF-511, Japan" i tradicionalno, pomoću merenja kožnih nabora kaliperom i daljim izračunavanjem pomoću matematičkih formula prema Slaughteru (1988). Nakon analize dobijenih rezultata, utvrđeno je da ne postoje statistički značajne razlike između procenta masnog tkiva dobijenog metodom bioelektrične impedanse i metodom merenja kožnih nabora tricepsa i leđa $(p=0,711)$ i tricepsa i potkolenice $(p=0,850)$ kod devojčica, dok su kod dečaka utvrđene statistički značajne razlike između rezultata dveju metoda $(p=0,001 ; p=0,009)$. Obe metode, kao najzastupljenije i praktično primenljive, pokazale su slične rezultate kod devojčica, dok isti slučaj nije kod dečaka.

Acta Medica Medianae 2019;58(3):153-158.

Ključne reči: masno tkivo, bioelektrična impedansa, kožni nabori, komparacija, adolescenti 